\title{
Knut Hamsun as a Literary and Film Character ${ }^{1}$
}

\author{
KATRIN KANGUR
}

Abstract. This article uses as a case study the historical-biographical drama film Hamsun (1996) in order to discuss the complications that arise when considering biographical films as adaptations of biographical and/or autobiographical works of literature. Hamsun by the Swedish director Jan Troell is an adaptation of the Danish author Thorkild Hansen's documentary novel Processen mod Hamsun (The Trial of Hamsun, 1978), which in turn draws most extensively on the Norwegian novelist Knut Hamsun's own writings, primarily his autobiographical novel Paa gjengrodde Stier (On Overgrown Paths, 1949).

Hansen, in telling the story of Hamsun's life, concentrates on the events surrounding the Second World War and its aftermath in Norway. The focus is set on the court trial of 1945-1948 when Hamsun was accused of being a quisling and his mental state was seriously questioned not only by the court, but also the general public. Hansen in his novel interprets his extensive source material with a very clear intention of rehabilitating Hamsun as a great writer with a brilliant mind instead of considering him a traitor. It is Hamsun's own perspective in Paa gjengrodde Stier that clearly lays the groundwork for Hansen's portrait of the writer. However, Hamsun's account of events is most selective: his often sharp and ironic descriptions of the present are combined with lyrical and philosophical reminiscences of the past, hardly providing the reader with any answers or explanations. The character Hamsun in Paa gjengrodde Stier seems to be a rather carefully constructed figure whose primary intent is to evoke the reader's sympathy and to remind us of his status as a writer, an artist.

The director Troell has said in several interviews that it was very important for him to use Hansen's book as source material, but that he and his screenwriter Per Olov Enquist have included many other sources, among them Hamsun's own Paa gjengrodde Stier. Viewing the film as an adaptation of Hansen's book, one easily recognizes the connections to Hamsun's own writings. An interesting question is whether or how the main character differs in each above-mentioned text. Naturally, the longer the period of time that separates the source material from the film adaptation, the more significant a role the changes that have occurred over time in social, political and ethical values play in our interpretation of depicted events. Hansen's portrayal of Hamsun was very original and controversial in its time. However, the release of the film Hamsun to an international audience in 1996 reopened the debate

The research has been supported by the Estonian Science Foundation (grant No 8874). 
of "Hamsun's guilt". Troell chose to focus on the drama of Hamsun's personal life through the war and its after-effects. The image of an artist instead of a collaborator - similar to what Hamsun created of himself on the pages of $\mathrm{Paa}$ gjengrodde Stier - prevails in both the novel and its film adaptation.

Keywords: biographical film, documentary novel, autobiographical novel, adaptation studies, Knut Hamsun, biography

DOI: http://dx.doi.org/10.12697/IL.2013.18.2.08

This article discusses the complications that arise when considering biographical films that are based on biographical or autobiographical works of literature using as a case study the Swedish director Jan Troell's historical-biographical drama Hamsun. The film is an adaptation of the Danish author Thorkild Hansen's documentary novel Processen mod Hamsun (The Trial of Hamsun), which in turn draws extensively on the Norwegian novelist Knut Hamsun's own writings, primarily his autobiographical novel $\mathrm{Paa}$ gjengrodde Stier (On Overgrown Paths).

The audience generally seeks out two basic "truths" when discussing biographical film: the commonly known historical and/or biographical facts and the film's correlation to these and the "credibility" of the portrayal of the main character. ${ }^{2}$ However, seeing popular historical or public figures from a new and unorthodox perspective can bring them and thus also the past into a different light. (This is also the case with Troell's Hamsun.)

Information on both the DVD-cover and in the title sequence of Troell's film Hamsun explains that it is "based on" (made after) Hansen's documentary novel Processen mod Hamsun. Troell has said in several interviews that with this film it was very important for him to use Hansen's book as source material, but that he and his screenwriter Per Olov Enquist "have included many other sources", among them Hamsun's own On Overgrown Paths. ${ }^{3}$ An interesting question is whether or how the main character differs in each above-mentioned text.

2 Giselle Bastin explains our expectations concerning biographical stories on screen as follows: "When people's lives are adapted to the screen, they are subject to the same appraisals and complaints that beset any form of film adaptation in the sense that the viewer can feel let down and betrayed by the film's lack of similarity to its source "text"." (Bastin 2009: 35)

3 Here I am referring to two interviews with Jan Troell by Estonian media, respectivly in 1997 and 1999, first with Tiit Merisalu (Merisalu 1997) and with Ülev Aaloe (Aaloe 1999) as well as to Ülev Aaloe's afterword to P. O. Enquist's Hamsun. En filmberättelse in Estonian translation (Aaloe 1998). 
KANGUR

Similarly to the genre of literary biography, biographical dramas or "biopics" are situated in the gray area between fiction and non-fiction. The term "biopic" seems to imply a variety of genres, ranging from serious documentaries to melodrama, action film or comedy. Various branches of cultural studies have only recently come to appreciate biographical film as a genre. George F. Custen's Bio/Pics: How Hollywood Constructed Public History published in 1992 was one of the first comprehensive histories of the genre. ${ }^{4}$ While discussing Hollywood "studio" biopic's effects on a wider audience's understanding of historical events, Custen points out the power of cinema's influence on the public's perception of "truth": "While most biopics do not claim to be the definitive history of an individual or era, they are often the only source of information many people will ever have on a given historical subject." (Custen 1992: 7)

Biographical films in general tend to follow two different patterns: those that claim documentary value and others that aim to reach more artistic goals. The latter take more than occasionally liberties with the biographical/historical facts for the sake of presenting a gripping story. ${ }^{5}$ Dennis Bingham's book Whose Lives Are They Anyway?... published in 2010 demonstrates that expectations for biographical film no longer include historical-biographical accuracythe "biopic", according to Bingham, is a genre that first and foremost gives the public the opportunity to actually experience a different life than their own.

Troell's film tells the story of the last 17 years of Hamsun's life. The film is set around the time of World War Two, including the years preceding the war and its aftermath, because of how these events affected the Hamsuns - both Knut and Marie and their four adult children. As such, the film can be viewed not only as the story of Hamsun's later years, but as the story of the whole family's fall from the highest status of social respect to the moral and legal condemnation after the war.

As Hamsun presents itself as an adaptation of Hansen's documentary novel, the question arises as to its "faithfulness" to the source material. Marianne Stecher-Hansen's article "Whose Hamsun?..." from 1999 analyzes the two

4 The biopic as a genre is defined by Custen as encompassing films in which "the characters' real names are used" (Custen 1992: 8). "The fact that real names are used in biographical films suggests an openness to historical scrutiny and an attempt to present the film as the official story of a life." (Custen 1992: 8)

5 Bingham summarizes this by saying that: "At the heart of the biopic is the urge to dramatize actuality and find in it the filmmaker's own version of truth. The function of the biopic subject is to live the spectator a story. The genre's charge, which dates back to its salad days in the Hollywood studio era, is to enter the biographical subject into the pantheon of cultural mythology, one way or another, and to show why he or she belongs there." (Bingham 2010: 10) 
texts behind the film, focusing on the ideological relationship between Hansen's Processen mod Hamsun and Enquist's film script published in the novel form (Hamsun. En filmberättelse. ${ }^{6}$ ) To give a short summary for comparison: Stecher-Hansen points out two major differences between Hansen's and Enquist's portrayal of Hamsun. She suggests that Hansen concentrates on finding an explanation for Hamsun's "guilt"; Enquist clearly tries to distance his book from that question by concentrating on the personal family tragedy of the Hamsuns. Regarding the question of whether it is possible to approach the last decade of Hamsun's life with any ideological neutrality, the article concludes that because Enquist accepts "Hamsun's Nazism as a foregone conclusion", it is doubtful that he has succeeded "in erasing the old notion of authorial genius, or whether Hamsun simply clouds the political implications of Knut Hamsun's tragedy" (Stecher-Hansen 1999: 251).

For a Norwegian audience the name of the novelist Hamsun invokes conflicting feelings. For much of his life, Hamsun was an author, literary critic and active in public life. Hamsun is connected to modernist, neo-romanticist and neo-realist movements. From the shadows of the " 4 giants" of $19^{\text {th }}$ century Norwegian cultural life - Bjørnstjerne Bjørnson, Alexander Kielland, Jonas Lie and Henrik Ibsen - Hamsun's novel Hunger (1890) broke the ground for a new literary movement in Scandinavian culture. As a Nobel Prize winner, he was one of the most prominent national cultural figures in Norway during the first half of $20^{\text {th }}$ century. In his later years however, Hamsun became notorious as a Nazi-sympathizer. His eulogy for Hitler, published in the Norwegian national newspaper Aftenposten, preceded by various other articles and public statements supporting the German occupation of Norway, was the key piece of evidence leading to his trial after the war. The Norwegian Supreme Court found Hamsun guilty of collaboration and he was required to pay a substantial fine. But more than the legal consequences, his reputation and place in the Norwegian cultural memory were tarnished. Not only were Hamsun's statements during the war generally viewed by Norwegians as a direct betrayal of their nation, but the contradictions between his public statements and the political reality at the end of war, were something that led many to doubt Hamsun's mental state. For many this opinion was confirmed by the results of Hamsun's psychiatric evaluation that preceded his trial, that concluded that the aging author suffered from "permanently impaired mental abilities" (varig svekkede sjelsevner). Hamsun responded in 1949, at the age of 90, by publishing his first book after more than a decade of literary silence: Paa gjengrodde Stier.

6 My reasoning for omitting here any closer scrutiny of P. O. Enquist's text is that this "film script in book form" was published as a separarate work following the film. 
The book sparked a heated discussion, not only because of the political issues surrounding it, but also in the literary world as "the last work of the Nobel prize winner Knut Hamsun”. When Paa gjengrodde Stier was first published ${ }^{7}$, many critics in the Nordic countries viewed this book as an autobiographical document of great importance, even though it was generally agreed that Hamsun's personal beliefs and political sympathies expressed during and after the war were morally wrong and the author's mental health in question. The audience clearly looked to this book first and foremost in order to find an insight into the controversial character of Hamsun, especially in connection to his actions supporting the Nazis and the resulting trial after the war.

Partially formatted as a diary, interwoven with reminiscences of youth, short fictional flashes and even poetry, the book refers to the whole life and first and foremost the art of the author, creating a circle back to the early years of his literary career. This perspective, however, opens up only if the reader is at least somewhat familiar with Hamsun's biography and writings. All in all, Paa gjengrodde Stier offers no rationale for Hamsun's fall from a position of pride and honor to face that accusation of traitor to his homeland. It shows instead the resulting repercussions that definitely manage to evoke the reader's sympathy.

The diary format of $\mathrm{Paa}$ gjengrodde Stier certainly seems, at first glance, to be a chronicle of the events of Hamsun's trial (the narrative begins with his arrest and dramatically ends with the sentence from the Supreme Court), but details are often vague. Few of his contemporaries are more than briefly mentioned and police and court investigators, doctors, nurses, attorneys or visiting family members and friends rarely recognized by name. ${ }^{8}$ As for responding to the accusations of his Nazi-sympathies, Hamsun is often sarcastically dismissive. Hamsun cites (Hamsun 1953: 148) his newspaper articles as the main motive for accusations against him; he states that he has never even known what the NS party stands for. ${ }^{9}$ When dealing with issues of his arrest and

7 After Hamsun's trial the publishing of this book was not an easy task - Hamsun did not find a publisher in Norway, thus Paa gjengrodde Stier was first printed and distributed in Sweden.

8 It is either that Hamsun expects the reader to be quite familiar with the details of his "case", or that he shows his contempt by omitting relevant information about people that he finds himself at odds with. One notable exception is Professor Gabriel Langfeldt, the leader of the psychiatric analysis and mental evaluation of Hamsun, cast as the definite villain of the story.

9 "Det som skal felle meg - til jorden - er ene og alene mine artikler i avisene. (...) Jeg har ikke vaert medlem av NS. (...) jeg vet ikke hva NS ånd er." (Hamsun 1953: 112) [That which shall bring me down - to Earth - are just and only my newspaper articles. (...) I have never been a member of NS party (...) I even don't know what NS stands for.] 
trial, it seems that Hamsun is rather misleading in his account, omitting many events or failing to present them chronologically. An example of this is his stay at the psychiatric hospital ${ }^{10}$ - here Hamsun cleverly uses different methods to approach the event that must have been a most traumatic experience for him. At first he refuses to give more information about this period, stating that "his only job now" is to answer written questions from Professor Langfeldt. The next entry is dated four months later when he is back at the nursing home in Landvik. He tentatively promises to return to this depressing time and give an account of it later, when he feels more distanced from it. First he does that in the documentary form: by including a draft of a letter to the state attorney, wherein he directly accuses Langfeldt of mistreatment and the invasion of privacy. This letter is dated more than seven months after his stay at the hospital. It is many pages later (these are filled with humorous recollections and anecdotes from his youth, contrasted by rather depressing account of everyday life here-andnow) that Hamsun in scathingly sarcastic descriptions returns to his stay at the hospital. Through such omissions and exaggerations Hamsun portrays himself as "Norway's first political prisoner" (Hamsun 1953: 12) - a lonely, isolated and humiliated man, who, despite his failing health and advanced age, has to accommodate society's righteousness and let the authorities conduct their petty investigations.

He stresses his belief that he is above the courts of his time, his actions will "be judged again in a 100 years".

This has indeed proven to be true: Paa gjengrodde Stier is often seen as a book that opens the past and looks into the mind of Hamsun, ${ }^{11}$ who under public scorn uses what means of defense are available to him. That is by constructing his image in a positive way through writing, asking at the same time for the reader's sympathy, but also hinting that even though he might be contemptible, his life writings have already cemented his place in the present and the future. However, even though Paa gjengrodde Stier is today generally considered to be

10 In Jan Troell's film Hamsun's stay at the psychiatric hospital is dramatized as an overwhelming and undignified experience. Parallels between the film, Hamsun's own accounts in Paa gjengrodde stier with Thorkild Hansen's narration are especially noticeable in these scenes.

11 In his thesis, Ola-Matti Mittigård analyses Paa gjengrodde stier from the perspective of discourse studies. His approach is that Hamsun's last novel is definitely written for the future. Mittigård stresses that it was "obligatory” for Hamsun - as he was then in public eye more of "an institution" than merely a man - to respond to his contemporaries, but it is for the future audience who no longer feels the immediate effects of WW II, that this work is intended. (Mittigård 2001: 121) 
a brilliant attempt at rhetorical defense (and defiance) by its author, ${ }^{12}$ the book does not answer the obvious question why? Hamsun himself as a writer has also attained a somewhat mythical status: he is often regarded as a "magician of words", ${ }^{13}$ using his power as a storyteller in Paa gjengrodde Stier to convince his audience to forget and forgive.

Interpreting the "mystery" of Hamsun's words and actions in connection with the war invites speculation. Various biographical investigation ${ }^{14}$ have attempted to offer an insight into this period in Hamsun's life. In his documentary novel Processen mod Hamsun (1978), the Danish author Hansen set out to "rehabilitate" Hamsun's character. Hansen not only shares Hamsun's own view that the passage of time will overwrite the question of guilt, but that when dealing with the mind of an artistic genius, a lot can and will be accepted and forgiven. Hansen was criticized for interpreting facts for his own purpose of bringing into question the concept of Hamsun's "betrayal". Hansen also presented the whole trial against Hamsun as unjust. His critics found Hansen's methods faulty; Gabriel Langfeldt even accused him of following Hamsun's autobiographical writings as a kind of gospel of truth. ${ }^{15}$

12 This text has been viewed from many different perspectives whether it is seen as a purely non-fictional text, analyzed using the psychoanalytical method or focused only on the lyrical and symbolic elements of the narrative. Perhaps the most comprehensive criticism of this as a literary work is provided in Steinar Gimnes book on the autobiographies in Norwegian literature (Sljölvbiografier. Skrift, fiksjon og liv, Det Norske Samlanget, Oslo, 1998) and Ståle Dingstad's Hamsuns strategier. Realisme, humor og kynisme (Gyldendal Norsk Forlag, Oslo, 2003).

13 The title "wizard of words" is often used when characterizing Hamsun's work. The words "trollmannens magiske penn" [a wielder of a magical pen] in connection with Paa gjengrodde stier is used to describe Hamsun's literary talent as an instrument to "bewilder" and "hypnotize" his audience. (As mentioned, for example, by Jörgen Haugan in his article in Aftenposten titled "Den Norske Hamsun-traume” ["Norwegian Hamsun-trauma"] (Haugan 2011).)

14 Perhaps the best internationally known are Hamsun's biographies by Robert Ferguson titled Enigma: The Life of Knut Hamsun (Hutchinson, London 1987) and Ingar Sletter Kolloen's two-bind Knut Hamsun: Dreamer \& Dissenter from 2009 (Ingar Sletten Kolloen, Erik Skuggevik and Deborah Dawkin, Yale University Press). The former of these books has also been adapted on screen: in 1996-1997 as first film, then re-worked into television series (Dir. Baardson, Bentein. Gåten Knut Hamsun. NRK/ Northern Lights AS 1996). Contrary to Troell's interpretation, this, more documentary version of Hamsun's life on screen, was mostly critically disapproved.

15 Following the publication of Hansen's book in Norway, the public debate reached such intensity that a selection of newspaper articles and other sources became published in a separate volume (Det uskyldige geni? Fra debatten om Prosessen mot Hamsun. Edited by Simen Skjönsberg, Gyldendal Norsk Forlag, 1979). Gabriel Langfeldt also answered by publishing his point of view on Hamsun's trial and especially the mental evaluation 
Hansen as an author was more often than not controversial in his thematic choices (for instance bringing to light long-forgotten issues such as the Danish slave trade $\left.{ }^{16}\right)$. Most of his popular books are written in the documentary novel style that Hansen introduced in Denmark, in which historical material is combined with subjective third-person storytelling and the author's commentary. His favorite biographical subjects seem to be anti-heroes and thus it is not surprising that the publication of his 3-volume work on Hamsun's trial reopened the heated public debate about "Hamsun's guilt" decades after the events.

Hansen, in telling the story of Hamsun's downfall, interprets his extensive documentary material with the intention of rehabilitating Hamsun as a great writer, not a traitor. Hamsun's own philosophical reminiscences of the past and often ironic descriptions of the present in Paa gjengrodde Stier clearly establish the groundwork for Hansen's portrait of the writer. However, as mentioned above, Hamsun's account of events can be considered selective; the character Hamsun in Paa gjengrodde Stier seems to be a carefully constructed figure whose intent is to evoke the reader's sympathy. We are confronted here with the myth of Hamsun's power as a writer, or as Marianne Stecher-Hansen points out:

[...] Hansen encountered a mixture of fact and artifice, promulgated by the main actors themselves in the form of literary memoirs, letters, postcards, responses to questionnaires, many of them undoubtedly artfully constructed with the verdict of posterity in mind. For Knut Hamsun in particular, everything was a matter of composition, of writing. Certain facts are withheld, others are embellished. How does even the most skillful documentarist glean the facts from fiction, when he is dealing with the finer nuances of the human psyche, the inner life and emotions of a master of prose and human psychology? (Stecher-Hansen: 248)

Because Hansen intentionally centers his book around Hamsun's perspective on events as told in Paa gjengrodde Stier, often quoting, paraphrasing or retelling whole paragraphs, it creates a life story on two levels: the echoes of an autobiographical voice and the interpretation of the character from the biographer's perspective. Treating autobiographical material as a source of equal documentary value, as was Hansen's method, includes in this case adapting the subjective viewpoint of the autobiographical storyteller to a biographical literary work told

(Ørnulv Ødegård and Gabriel Langfeldt, Den rettspsykiatriske erklering om Knut Hamsun, Gyldendal 1978).

16 In his trilogy Coast of Slaves and Ship of Slaves (both 1967, in English 2002 and 2005 respectively) and Island of Slaves (1970, English translation 2007). 
in the $3^{\text {rd }}$ person. With autobiographical texts, in the form of published memoirs, diaries or even semifictional autobiographical novels, readers naturally assume that the author of the text, the narrator and the protagonist are one and the same person. In the autobiographical text, the reader expects to find the author's personal evaluation of events. The person behind the text should somehow be revealed through it. These thoughts and emotions are accepted as the subjective viewpoint of the author, the truth as he or she sees it, not necessarily the truth and nothing but. ${ }^{17}$ However, biography as a genre cannot enjoy the same "freedom": biography is expected to give both a broader and more objective picture of a person's life and certainly follow the historical and biographical facts. Still, without using autobiographical materials as sources, the writer of a biography can in no way render the thoughts and feelings of his main character without becoming fictional. A biographical film can evoke emotional empathy for the character on the screen - through camera work we can see what the characters "see", their body language conveys emotions, etc. - but still the viewer of a biographical film does not have direct access to the inner world of the autobiographical "I". Some have argued that this is also the reason why something essential is inevitably lost when an autobiography is adapted into a biographical text (either of a book or a film). ${ }^{18}$ However, if film adaptation and its source text(s) are seen as works of equal original value, adding an autobiographical layer to a biographical film - through the voice-over technique for example - provides an insight into the mind of the character, the combination which adds to the spectator's view and our ability to identify the actor with an actual historical person.

Troell's film interpretation of the final years of Hamsun's life opens with a quotation from the latter's early novel Under Høststjcrnen. En Vandrers Fortcelling. 1906 (Under the Autumn Star). We see a "younger Hamsun" (portrayed by Max von Sydow) sitting at his desk and writing about travelling "on overgrown paths", quoted by a voice-over ("As I walk down the overgrown

17 This has been summarized as the different ways the reader can and will identify with the protagonist of the story: "Generally, the reader of a biography can be compared to a person examining a portrait or viewing a performer on stage. The sympathetic reader of autobiography is summoned through empathy, and may remember moments more vividly than simply facts." (Jolly 2001: 78)

18 With regards to memoirs made into movies, William Mooney has pointed out that "the written memoir, because of its peculiar dependence on the interrelation of author and protagonist by way of the first-person narration, inherently resists adaptation into film by someone other than its author. [...] eliminating the "auto" from the autobiography typically transforms the written memoir into a flat reenactment of past events, "based on a true story", yet presented from an entirely different perspective, to be viewed and evaluated as a completely different kind of work." (Mooney 2007: 294) 
path through the forest... (Hamsun. Dir. Jan Troell. 1996, 00:17-00:19) With these opening frames, the film has already created an image of Hamsun the writer, the artist.

Although the chronology is often interrupted and the narrative fragmented, the film can easily be divided into two parts. First, the story's background is introduced by showing Hamsun's family and the conflict between him and his wife Marie. In this case the movie follows Hansen's interpretation of events in which Marie Hamsun is cast as the main reason why the family became closely connected with the Nazis. The events before and during the Second World War are mostly depicted through Hamsun's family's eyes. Knut appears in conjunction with well-known biographical events: his $80^{\text {th }}$ birthday celebrated with guests from Germany and local NS leaders, later meetings with Hitler, Terboven and Quisling. Hamsun is portrayed as being deeply concerned with the actions of the occupants as he tries to use his influence to attain better treatment for political prisoners, especially fellow artists and young men from his home village - this is also something that Hamsun himself in Paa gjengrodde Stier gives as his motivation for newspaper articles calling for surrender and cooperation. In the second half of the film, following Hamsun's arrest, the main character becomes the central focus.

As an author, Hamsun is known as the great interpreter of the struggles of man in the modern world, focusing on keywords such as inner isolation and estrangement. Whereas Hansen looks for explanations and reasons for Hamsun's downfall, Hamsun "explains" himself as if he were simply a bystander. This is also Troell's portrait of him. Paa gjengrodde Stier is a psychological portrait following the "rules of the game": the author goes back to his character's ${ }^{19}$ youth, even his childhood, remembers the cruelty of his uncle, dedicates a sweet poem to his mother, and tells short stories about his travels and past lovers, never really reasoning or connecting any of that to the story of his "betrayal". The main motivational drive for character Hamsun in either Paa gjengrodde Stier, Processen mod Hamsun or Troell's film interpretation seems to be a longing for some kind of conclusion. The "character Hamsun" that the reader looks for on the pages of Paa gjengrodde Stier is best pictured through his interactions with people around him, through short dialogues and anecdotes. It is here that one can find many direct parallels between Paa gjengrodde Stier and Troell's interpretation of Hamsun. The film's second part puts a great emphasis on depicting small details of Hamsun's everyday life after his arrest, bringing the

19 The character in the past is given the name Knud (Knud Pedersen was the name Hamsun was christened with), but a third person pronoun is used. 
KANGUR

character closer to us on a personal level, even though these scenes might often be inconsequential to the story's progression as such.

For example, a scene (Hamsun. Dir. Jan Troell. 1996, 1:31:23-1:32:33) that takes place at the retirement home where he is kept under house arrest. A police officer, Mr. Christensen, asks Hamsun questions pertaining to his trial, about his income and financial assets, his political writings, etc. Hamsun ignores these questions, finding them unimportant, and is interested instead in the policeman's new bicycle. ${ }^{20}$ This interest, if somewhat confusing, manages, nevertheless, to bring a smile to Officer Christensen's face. This scene with the police officer's bicycle can be found in Hamsun's own book, but Hansen's documentary novel gives it a broader interpretation (found in Hansen: 1978, part 1 , chapter 13). It has been pointed out ${ }^{21}$ that Hansen often transcribes whole paragraphs of Hamsun's book into the $3^{\text {rd }}$ person and it is sometimes difficult for the reader to distinguish Hamsun's words from Hansen's:

Jeg skulle ønske jeg eide den fine cyklen Deres, sier jeg.

Vil De ikke læse erkleringen, sier han.

Nei, ikke netop det, men. (Paa gjengrodde Stier, Hamsun 1953: 8)

Hamsun lod hånden med brevet falde og kikkede interessert på politimandens cykel: - Jeg ville ønske, jeg havde en lige så fin cykel som Dem, sagde han. Politikonstabel Finn Christensen så forvirret på ham. - Ja men, vil De ikke læse erklæringen? spurte han. - Nej, ikke netop det, men... Hamsun afbrød sig selv. Politikonstabel Finn Christensen forstod nok ikke ironi. ${ }^{22}$ (Processen mod Hamsun I, Hansen 1978: 208)

Obviously this scene provided by Hamsun is asking for an interpretation. Hansen's Hamsun is rather sarcastic towards the policeman; Hansen gives his authorial evaluation that this is Hamsun countering authorities by ridiculing Finn Christensen. The scene in Paa gjengrodde Stier (Hamsun 1953: 7-8) creates more an impression that Hamsun is simply rather wistful and envies the

20 [Hamsun:] That's a mighty fine bicycle you have there, Mr. Christensen. - [Policeman:] It's a Crescent. - [Hamsun:] I'd have liked one like that. (Hamsun. Dir. Jan Troell. 1996, 1:31:27-1:32:33)

21 A detailed page by page comparison of the two texts can be found in: Dokumentasjon som alibi. Thorkild Hansens bruk av Hamsunkilder i sin dokumentariske roman Processen mod Hamsun, Ingunn Fredheim Syvertsen, Oslo Universitet, 1983.

22 Hamsun let his hand with the letter fall and gave the policeman's bicycle an interested look: - I wish I owed such a fine bicycle, he said. Constable Finn Christensen looked confused - Yes, but, don't you want to read your statement?, he asked. - No, not quite that, but... Hamsun cut off. Officer Finn Christensen didn't quite understand the irony. 
policeman's youth and freedom - something that he himself does not have. The film also adds another twist - a short amorous encounter between the police officer and the nurse in a point-of-view shot that Hamsun observes through his window. What Hamsun sees here - the relationship between the policeman and the nurse - might never have happened, but it adds something to the portrayal of his character. This digression has literally nothing to do with the development of the storyline nor does it represent any important historical details, neither is the policeman's (rather earnest and naïve) character in any way important to the overall story in the film. This scene is one of the many that portrays Hamsun much like the writer presents himself in the pages of Paa gjengrodde Stier - an observer and interpreter of human psychology and emotions, interested in short everyday stories of the people around him, even though he might view these stories with humor and sets himself above these people.

If the audience is not familiar with the writing "behind" the film, they often find their way to it afterwards (as is common with popular literary adaptations). There is a noticeable time gap between Hamsun's autobiographical novel (first published in 1949), Hansen's book of 1978 and the film that appeared as recently as 1996. Both Enquist's Hamsun. En filmberättelse (1996) and a reprint of Hansen's Processen mod Hamsun were published following the film in Scandinavia. Shortly after the film gained international fame and was released worldwide, a new English translation of Paa gjengrodde Stier (by Sverre Lyngstad, 1997) was published.

However, in the case of a biographical film, including those based on a life-story in book form, there is always the "real life lived" and the historical events to consider. Custen discusses (Custen 1992: 32-34) how biopics manage to create a very different image of the past from that of the history books by bringing the past closer through the experiences of an individual caught in the historical events. There are of course many factors involved in creating a "believable" portrait of an actual (historical) person, and most often there are many varied sources that support the final creation of the persona we meet on screen. Here the successful casting of the actor in the role of the main character is naturally rather important. ${ }^{23}$ Usually the historical or biographical films

23 Yet, the more "in character" the actor, the easier it seems to be for the image of a "star" to superimpose itself on that of an actual historical person. The Swedish actor Max von Sydow won several awards for his performance. Stecher-Hansen points out how casting can add to the meta-level of the audience's understanding of a historical person: as a result of the actor's previous roles (especially as $19^{\text {th }}$ century farmer in The Emigrants (1971, also directed by Troell), his portrayal of Hamsun "serves to reinforce the image of the author as a man rooted in humble and staunch peasantry" (Stecher-Hansen 1999: 251). 
KANGUR

are confronted with the choice of disregarding or using documentary images of their characters as a part of or to supplement to the story. The conflict of documentary and fictional images might break the film's illusion of "reality" created by actors.

Films are also able to show the past through images that represent certain cultural codes (or clichés) about the historical era. ${ }^{24}$ Troell's use of documentary images has more in common with fictional historical drama and less with the biographical film as a documentary genre: he does not show a single piece of archive footage of Hamsun nor his family. The documentary material in Hamsun is used to create the general atmosphere, breaking the narrative or linking different scenes together. The only time that these images have an actual place in the storyline is when Hamsun (while he is going through the mental evaluation at the psychiatric hospital) is shown horrified by images of concentration camps. Historical events and documentary material used in Hamsun are also closely connected to the personal stories of the film characters. (For example an aerial view of a bombed out city in Hamsun (1:30:36-1:30:39) that is followed by scenes describing the fall of the local Nazis in Norway and also consecutively that of Hamsun's family). From this perspective, it could be said that this movie is as much about Norway's occupation as it is about Hamsun's personal life.

Naturally, the longer the period of time that separates the source material from the film adaptation, the more significant a role the changes that have occurred over time in social, political and ethical values play in our interpretation of depicted events. One possible conclusion is that a gap in time between the "original" and the film adaptation sometimes means that the subject matter has lost some of its political and/or ideological sensitivity. Conversely, it might reopen festering wounds in the collective memory, as occurred with the release of the film Hamsun and publishing of Hansen's book. Hansen's portrayal of Hamsun was very original in its time as he is shown to be a victim instead of a wrongdoer: he is portrayed as a "Socrates from Grimstad", a genius suffering for his idealistic beliefs. Troell focused on the drama of Hamsun's personal life (at times his story approach melodramatic heights). As artistic representations

24 Thus, for example Nazi Germany is more often than not represented with documentary images of Hitler's public speeches, the footage showing concentration camps, invasions of occupied capitals, and finally the jubilation of the freedom celebrations. (There are surprisingly many historical films that re-use exactly the same documentary images and they often seem to have no other purpose than to be simple iconographic identifications of WW II.) In the film Hamsun, many of these easily recognizable documentary images, both film and photo materials, have been used. 
Knut Hamsun as a Literary and Film Character

of the character of Hamsun, these literary and film texts are constructed following the image created by Hamsun himself.

\author{
Katrin Kangur \\ katrin.kangur@ut.ee \\ Tartu Ülikool \\ Kultuuriteaduste ja Kunstide Instituut \\ Ülikooli 16 \\ 51014 Tartu \\ EESTI
}

\title{
Bibliography
}

Aaloe, Ü., Saluäär, A. 1998. Järelsõna: Knut Hamsun, P.O.Enquist, Jan Troell. P. O. Enquist, Hamsun. Filmijutustus. Tallinn: Perioodika, 37/38, 129-133.

Aaloe, Ü. 1999. Jan Troelli nimi on garantii. Ingmar Bergman nimetab klassikuks saanud Troelli säravaks geeniuseks. - Postimees: Kultuur, 12.07.

Bastin, G. 2009. Filming the Ineffable: Biopics of the British Royal Family. $-a / b$ : Auto/Biography Studies, 24, 1, 34-52.

Bingham, D. 2010. Whose Lives Are They Anyway? The Biopic as Contemporary Film Genre. New Brunswick: Rutgers University Press.

Custen, G. F. 1992. Bio/Pics: How Hollywood Constructed Public History. New Brunswick: Rutgers University Press.

Enquist, P.O. 1996. Hamsun : en filmberättelse. Stockholm: Norstedt

Troell, J., dir. 1996. Hamsun. Nordisk Film 2004 [DVD].

Hamsun, K. 1953. Paa gjengrodde stier. Oslo: Gyldendal Norsk Forlag.

Haugan, J. 2011. Den Norske Hamsun-traume. - Aftenposten, 19.10, http://www.aftenposten.no/meninger/kronikker/article896537.ece\#.TAzA9mmuuO (05.10.2013)

Jolly, M., ed. 2001. Encyclopedia of life writing: Autobiographical and Biographical Forms, Vol. 1-2. London, Chicago: Fitzroy Dearborn.

Merisalu, T. 1997. Jan Troell: Hitlerist hukkunud naispiloodini. - Eesti Ekspress, 1997, nr 41, 10.10.1997 - http://blog.ekspress.ee/Arhiiv/Vanad/1997/41/tvnadal/ portree.html (05.10.2013)

Mittigård, O.-M. 2001. Mannen er dikteren. Dikteren er mannen. Knut Hamsuns Paa gjengrodde stier $i$ en diskursanalytisk ramme. Hovedfagsoppgave i nordisk litteratur. Trondheim: Institutt for nordistikk og litteraturvitenskap, Norges teknisknaturvitenskapelige universitet NTNU.

Mooney, W. 2007. Memoir and the Limits of Adaptation. - J. M. Welsh, P. Lev, eds., The Literature/Film Reader: Issues of Adaptation. Lanham, Maryland: The Scarecrow Press, 285-296. 
KANGUR

Stecher-Hansen, M. 1999. Whose Hamsun? Author and Artifice: Knut Hamsun, Thorkild Hansen and Per Olov Enquist. - Edda, 2, 245-251.

Syvertsen, I. F. 1983. Dokumentasjon som alibi. Thorkild Hansens bruk av Hamsunkilder $i$ sin dokumentariske roman „Processen mod Hamsun”. Oslo: Oslo Universitet. 